\title{
Long-term adaptation of pancreatic response by dogs to dietary fats of different degrees of saturation: olive and sunflower oil
}

\author{
By M. C. BALLESTA, M. MAÑAS, F. J. MATAIX, E. MARTINEZ-VICTORIA* \\ AND I.SEIQUER \\ Instituto de Nutrición y Tecnologia de Alimentos, Departamento de Fisiología, Facultad de \\ Farmacia, Universidad de Granada, Granada, Spain
}

(Received 27 June 1989 - Accepted 18 April 1990)

\begin{abstract}
Mongrel dogs were fed, from weaning to 9 months of age, on one of two diets that differed only in the type of fat content (virgin olive oil or sunflower oil) to compare the composition of exocrine pancreatic secretion in the basal period and in response to food. In resting pancreatic flow, electrolytes and the specific activities of amylase, lipase and chymotrypsin were similar in both experimental groups. However, lipase and amylase outputs, and amylase and protein concentrations were significantly higher in the group fed on the diet rich in sunflower oil. Food intake was not followed by any change in flowrate or electrolyte or protein content in the group given the diet rich in olive oil. Amylase activity and output were also lower in this group, as was lipase output, whereas activity and specific activity of chymotrypsin were lower in dogs fed on the diet containing sunflower oil. The differences traceable to the composition of the two types of dietary fat supplied may be related to the balance between factors that stimulate and inhibit pancreatic secretion.
\end{abstract}

Dietary fat: Pancreatic secretion: Dog

The adaptation of pancreatic enzymes to the type of food available is one of the physiological advantages that allow animals to use nutrients and energy for metabolism as efficiently as possible. A number of studies have analysed the adaptation of pancreatic enzymes to the presence of different substrates in the diet. Rising levels of dietary fat lead to parallel increases in lipase $(E C 3.1 .1 .3)$ activity in rat pancreas homogenates (Bucko et al. 1969; Robberecht et al. 1971; Deschodt-Lanckman et al. 1971; Snook, 1971; Sabb et al. 1986; Bazin \& Lavan, 1979; Wicker \& Puigsever, 1987). The degree of unsaturation appears to have no effect on pancreatic levels of lipase (Saraux et al. 1982), whereas the length of the fatty acid chain has been shown to influence lipase levels in this organ (Saraux et al. 1982).

In the rat, the amount of dietary fat affects amylase (EC 3.2.1.1) activity and protease content in the exocrine pancreas. Changes in amylase are the inverse of those in lipase: amylase activity declines as the amount of dietary fat increases (DeschodtLanckman et al. 1971; Snook, 1971; Saab et al. 1986; Wicker \& Puigsever, 1987). The extent of this decrease is influenced by the length and the degree of unsaturation of dietary fatty acids (Saraux et al. 1982). Trypsin (EC 3.4.21.4) and chymotrypsin (EC 3.4.21.1) are modified in the same direction as lipase when the amount of dietary fat rises (Snook, 1971; Wicker \& Puigsever, 1987).

Although most studies on the adaptation of pancreatic enzyme levels have been performed in the rat, other species used to date include the dog (Behrman \& Kare, 1969), the pig (Corring \& Saucier, 1972; Low, 1982; Partridge et al. 1982; Simoes-Nunes, 1985), and man (Ekelund \& Johanson, 1980; Emde et al. 1985). While the overall patterns of 
adaptation seen in these species are partially comparable to those in the rat, the differences become more significant between this animal and man.

The presence of fat, especially its digestive products the monoglycerols and fatty acids, in different segments of the intestine is known to affect the volume as well as the bicarbonate and enzyme content of exocrine pancreatic secretion (Meyer \& Jones, 1974; Yamagishi \& Debas, 1980; Faichney et al. 1981; Malagelada et al. 1985). To date, however, no studies have dealt with the long-term pancreatic adaptation to high levels of specific nutrients in the diet. Excessive amounts of dietary fat can affect not only hydrolase levels in tissue and pancreatic juice but also the overall pattern of pancreatic response to the presence of food in the digestive tract.

The present article describes the long-term adaptation of exocrine pancreatic secretion in the dog to high levels of two types of dietary fat, which differ in fatty acid unsaturation: sunflower oil, rich in polyunsaturated fatty acids, and virgin olive oil, a fat source of high monounsaturated fatty acid content. The effects of these two diets were analysed in terms of (1) pancreatic response to food and (2) enzyme content in the pancreatic juice secreted.

\section{MATERIALS AND METHODS}

\section{Animals}

The subjects were mongrel dogs of both sexes weighing $15-25 \mathrm{~kg}$. The animals were weaned (at 15-20 d of age) and randomly assigned to one of the two experimental groups. Subjects in group $\mathbf{S}$ (four animals) and group $\mathrm{O}$ (four animals) were fed on diets in which the source of fat was sunflower oil and olive oil respectively. During the 8-month adaptation period, all dogs were housed in individual cages with free access to water. Feeding took place once daily between 09.30 and 12.00 hours to adapt the animals to the experimental regimen and avoid conditioning to a specific feeding time.

\section{Diets}

The diets used were prepared from commercial dog chow (Extra ${ }^{\mathbb{B}}$, Gabrina Purina) made up specially for the present study, omitting fat. Sunflower oil (Koipesol ${ }^{\circledR 8}$; Koipe S.A., Jaén, Spain) was added to the chow given to group $S$, and virgin olive oil (Patrimonio Comunal Olivarero, Madrid, Spain) was added to the chow given to group $\mathrm{O}$ animals.

There were no marked differences between the plant sterol content or tocopherol content in the two dietary fats, the concentration of which was very small compared with the saponifiable fraction.

Antioxidant levels or peroxide values were not measured because the diets were prepared every day, and the correct amount of 'fresh' oil (olive or sunflower) added to avoid peroxidation. The two oils were stored in 1 litre closed bottles in the dark for short periods (no longer than 1 week) before use.

Table 1 summarizes the composition of the two diets, which aside from their different fat sources were isoenergetic and isonitrogenous and thus differed only in fatty acid composition. Table 2 shows the percentage content of each fatty acid in both diets.

\section{Surgical preparation}

After a $20 \mathrm{~h}$ fast with free access to water the animals were anaesthetized with a $30 \mathrm{mg} / \mathrm{kg}$ body-weight dose of sodium thiopental (Tiobarbital ${ }^{\circledR}$; Miró S.A., Jaén, Spain). Intubation was performed under direct laryngoscopic vision using a Rush-type pressure-cap tube. During surgery the animals were connected to a Boyle-type open respiratory system (Medishield; B.O.C., London) using a mixture of oxygen and nitrous oxide bubbled through a Halothane solution (Ethrane ${ }^{\mathbb{E}}$; Abbot Laboratories S.A., Madrid, Spain). 
Table 1. Composition of the experimental diets

\begin{tabular}{|c|c|c|c|c|c|c|}
\hline & \multicolumn{3}{|c|}{ Sunflower oil diet } & \multicolumn{3}{|c|}{ Olive oil diet } \\
\hline & \multicolumn{2}{|c|}{$\mathrm{g} / \mathrm{kg}$} & \multirow[b]{2}{*}{ Energy $(\%)$} & \multicolumn{2}{|c|}{$\mathrm{g} / \mathrm{kg}$} & \multirow[b]{2}{*}{ Energy $(\%)$} \\
\hline & Mean & $\mathrm{SE}$ & & Mean & $\mathrm{SE}$ & \\
\hline Protein & 218 & $4 \cdot 5$ & $19 \cdot 4$ & 222 & 3.9 & $19 \cdot 4$ \\
\hline Fat & 159 & $9 \cdot 0$ & 31.9 & 174 & $4 \cdot 6$ & $34 \cdot 4$ \\
\hline Carbohydrate & 546 & $11 \cdot 1$ & $48 \cdot 7$ & 527 & 4.9 & $46 \cdot 2$ \\
\hline Ash & 77 & $2 \cdot 0$ & - & 77 & $1 \cdot 8$ & - \\
\hline
\end{tabular}

The dog chow (Extra Gabrina Purina), which was the basal diet for the above experimental diets, contained $(\mathrm{g} / \mathrm{kg})$ : dry matter 880 , crude protein 210 , fat 0 , fibre 35 , ash 80 , sodium chloride 12 , calcium 15 , phosphorus 9 , choline 2 and $(\mathrm{mg} / \mathrm{kg})$ : iodine $1 \cdot 3$, magnesium 80.0, copper $30 \cdot 0$, iron 400.0 , zinc 140.0 , cobalt $1 \cdot 0$, retinol equivalent $6 \cdot 0$, vitamin $\mathrm{E} 13 \cdot 4$, thiamin $10 \cdot 0$, riboflavin $8 \cdot 0$, pyridoxine $10 \cdot 0$, cyanocobalamin equivalent $0 \cdot 3$, menadione $1 \cdot 0$, cholecalciferol equivalent $0 \cdot 05$, nicotinic acid $80 \cdot 0$, folic acid 5.0, pantothenic acid 25.0.

Table 2. Fatty acid composition of experimental diets ( $\%$ total fatty acid content)

\begin{tabular}{lcc} 
Fatty acid & $\begin{array}{c}\text { Sunflower } \\
\text { oil diet }\end{array}$ & $\begin{array}{c}\text { Olive oil } \\
\text { diet }\end{array}$ \\
\hline Palmitic $(16: 0)$ & $9 \cdot 1$ & $11 \cdot 7$ \\
Stearic $(18: 0)$ & $3 \cdot 5$ & $2 \cdot 4$ \\
Oleic $(18: 0 n-9)$ & $25 \cdot 5$ & $60 \cdot 9$ \\
Linoleic $(18: 2 n-6)$ & $56 \cdot 3$ & $15 \cdot 3$ \\
Linolenic $(18: 3 n-3)$ & $2 \cdot 3$ & $0 \cdot 8$ \\
\hline
\end{tabular}

After medial laparotomy, the main pancreatic duct was cannulated according to the technique of White \& Murat (1967), using a silastic cannula with a rigid PVC tip. Near the drainage of the main pancreatic duct, a ' $\mathrm{T}$ ' cannula was implanted in the duodenum and fixed to the intestinal wall with purse-string sutures. Both cannulas were exteriorized through the right abdominal wall. The experiments began 1 week after surgery.

\section{Time-course of the experiments}

The animals were deprived of food but not water for $20 \mathrm{~h}$ before starting the experiments. After collecting two $60 \mathrm{~min}$ samples of pancreatic juice, the dogs were fed and pancreatic secretions were sampled hourly for the next $5 \mathrm{~h}$. All samples were collected into PVC bags. Flow-rates were determined gravimetrically with density considered equal to 1 (Hoffman, 1963). A portion was taken from all samples for the immediate determination of bicarbonates, and a portion of each sample was frozen at $-20^{\circ}$ for subsequent analysis. The rest was recirculated into the duodenum to avoid possible interferences.

Together with pancreatic juice, the duodenal contents were sampled at the same time intervals to determine $\mathrm{pH}$ (Crisson ${ }^{(*)} \mathrm{pH}$ meter, model MicropH 2001 ; Crisson Instruments S.A., Barcelona, Spain).

\section{Analytical methods}

Bicarbonates were determined in $0.5 \mathrm{ml}$ pancreatic juice to which $5.0 \mathrm{ml} 0.01 \mathrm{M}$-hydrochloric acid was added, followed by heating to the boiling point and cooling. The acid residue was neutralized with $0.01 \mathrm{M}$-sodium hydroxide, and the results were expressed in $\mathrm{mmol} / \mathrm{l}$ (Debas \& Yamagishi, 1978).

Amylase activity was measured by hydrolysis of the starch substrate and determination 

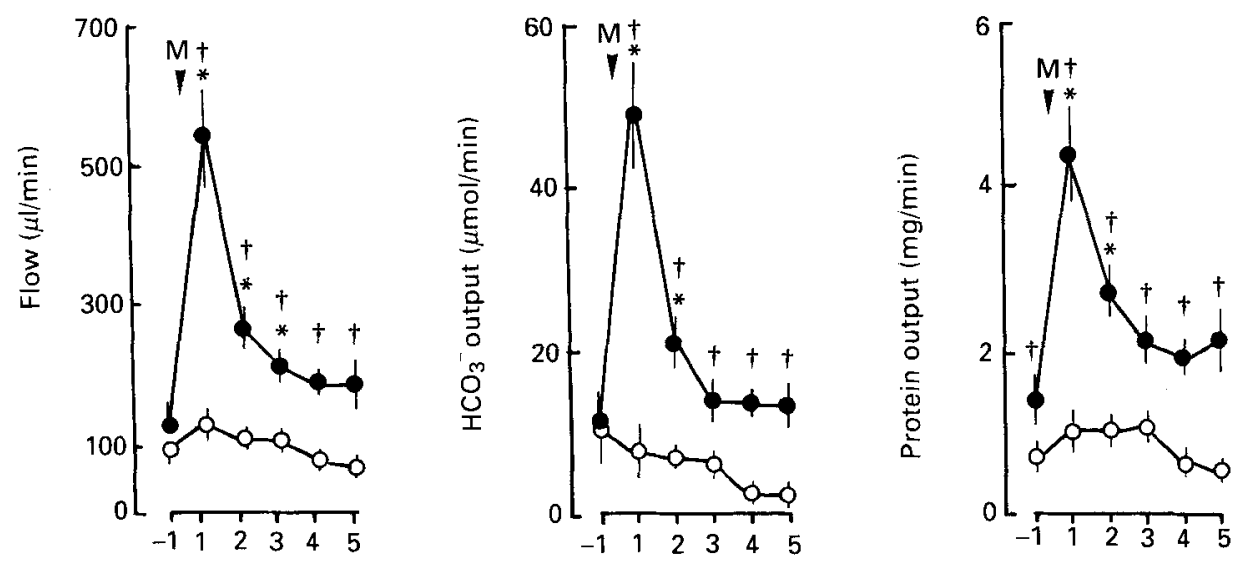

Period after food intake (h)

Fig. 1. Volume of pancreatic juice flow, and bicarbonate and protein output under resting conditions (time - 1) and after food intake (M) in dogs fed on diets containing sunflower oil (O) and olive oil (O). Values are means, with their standard errors represented by vertical bars for three experiments/dog. Mean values for the two dietary groups were significantly different from those under resting conditions: ${ }^{*} P<0.05$. Mean values for the two dietary groups were significantly different : $† P<0 \cdot 05$.

of the amount of maltose released, in accordance with the technique described by Noelting \& Bernfield (1948), as modified by Hickson (1970). The results were expressed in units of activity as defined by Hickson (1970).

Lipolytic activity was determined using the technique of Negrel et al. (1976), by titration at a constant $\mathrm{pH}(8.5)$ with tributyrine as the substrate. The unit of lipase activity was defined as that amount of lipase able to release $1 \mu \mathrm{mol}$ acid $/ \mathrm{min}$ at $27^{\circ}$.

To determine chymotrypsin activity, titration was performed at a constant $\mathrm{pH}(7.9)$ with acetyltyrosine ethyl ester (ATEE) as the substrate. Chymotrypsin was previously activated with trypsin. Activity was expressed in $\mu \mathrm{mol}$ ATEE hydrolysed $/ \mathrm{min}$ at $27^{\circ}$ (Rebound et al. 1962).

Protein was determined as described by Bradford (1976).

\section{Statistical treatment}

For comparisons of the means within and between experimental groups, Mann-Whitney's non-parametric $U$ test and Student's $t$ test were used. The differences were considered significant when $P \leqslant 0.05$.

\section{RESULTS}

\section{Food intake}

There were no differences in food intake between the groups. All the animals ate the same amount of food $(500 \mathrm{~g} / \mathrm{d})$ and they had the same energy intake during the experimental period.

\section{Resting secretion}

The pancreatic flow-rate was similar in both experimental groups, slightly but not significantly higher in dogs fed on the diet containing sunflower oil (Fig. 1). Likewise, bicarbonate levels were not significantly different (Fig. 1). However, protein content was higher in juice secreted by group $S$ animals $(P<0.05)$ (Fig. 1), and amylase activity as well as the output of this enzyme were also significantly greater in this group (Fig. 2). Lipase secretion, but not activity, was significantly higher in animals given sunflower oil (Fig. 2). 
Activity $(\mathrm{U} / \mathrm{ml})$
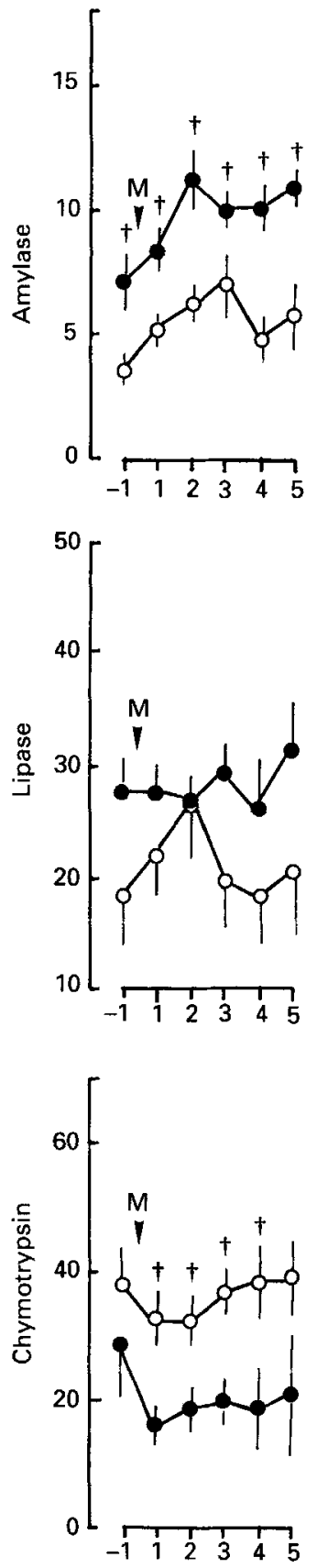

Output (U/min)
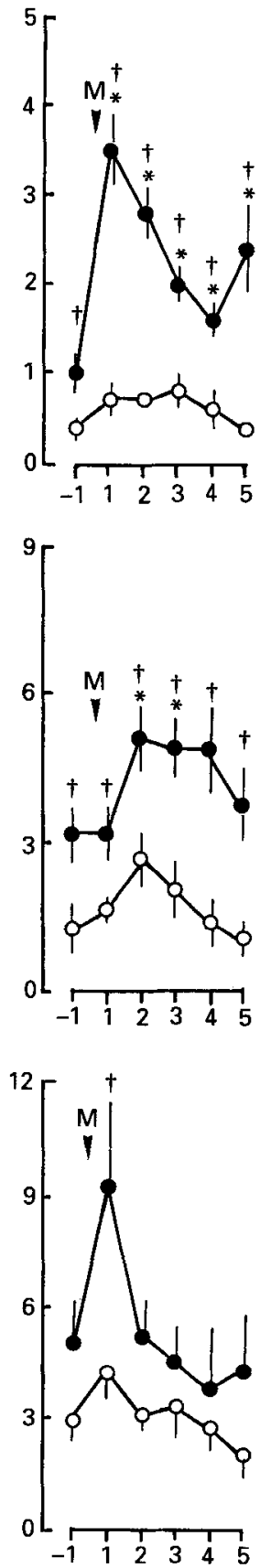

Specific

activity (U/mg protein)
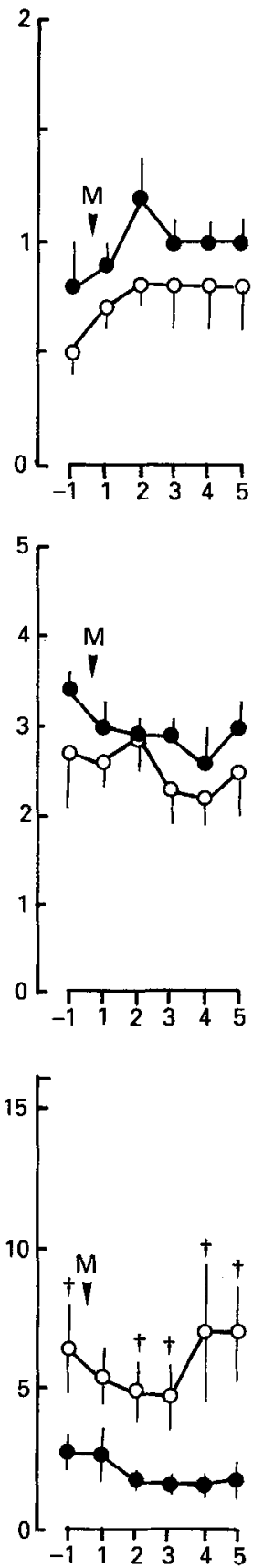

Period after food intake (h)

Fig. 2. Activity, output and specific activity of amylase (EC 3.2.1.1), lipase (EC 3.1.1.3) and chymotrypsin ( $E C$ 3.4.21 .1) under resting conditions (time -1 ) and after food intake (M) in dogs fed on sunflower seed oil ( $O)$ and olive oil $(O)$. Values are means, with their standard errors represented by vertical bars for three experiments/dog. Mean values for the two dietary groups were significantly different: $\dagger P<0.05$. Mean values for the two dietary groups were significantly different from those under resting conditions: ${ }^{*} P<0 \cdot 05$. 


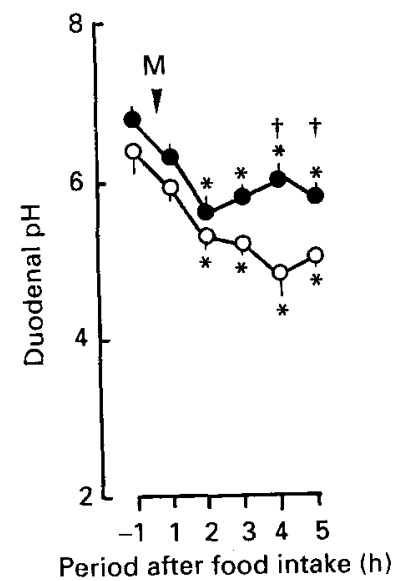

Fig. 3. Duodenal $\mathrm{pH}$ values under resting conditions (time -1 ) and after food intake (M) in dogs fed on sunflower seed oil $(O)$ and olive oil $(O)$. Values are means, with their standard errors represented by vertical bars for three experiments $/ \mathrm{dog}$. Mean values for the two dietary groups were significantly different $\uparrow P<0 \cdot 05$. Mean values for the two dietary groups were significantly different from those under resting conditions: ${ }^{*} P<0 \cdot 05$.

Despite the slightly higher value for chymotrypsin activity in pancreatic juices from group $\mathrm{O}$, the difference was not statistically significant (Fig. 2). The specific activities of amylase and lipase were similar in both groups, while chymotrypsin specific activity was significantly higher in dogs fed on virgin olive oil (Fig. 2).

\section{Response to food}

The two groups responded differently to the presence of food in the digestive tract. In group $\mathrm{S}$, there was a significant increase in the volume of pancreatic juice secretion during the first $3 \mathrm{~h}$ after food intake, while the flow of pancreatic secretion showed no change throughout the entire postprandial period in group $\mathrm{O}$ animals (Fig. 1). Overall, flow was greater in group $S$ during the entire period of study.

In animals given the diet high in polyunsaturated fatty acids, food intake led to a marked rise in bicarbonate levels during the first $2 \mathrm{~h}$ after eating. In group $\mathrm{O}$, however, no significant change was recorded throughout the entire postprandial period. Bicarbonate production was consistently higher in group $\mathrm{S}$ dogs (Fig. 1). A very similar pattern was shown by protein output (Fig. 1).

Amylase activity in the pancreatic juice showed no significant change after food intake in either group. The activity of this enzyme was nevertheless consistently higher in group $\mathrm{S}$ (Fig. 2). Amylase output rose significantly after feeding and remained elevated during the following $5 \mathrm{~h}$, in contrast with the lack of change in group $\mathrm{O}$ during this period. Specific activity of amylase behaved similarly in both groups, with no significant changes in response to food. No significant difference between the two groups was found in postprandial specific amylase activity.

Lipase activity and specific activity showed no significant change in response to food in either of the experimental groups. Neither of the two variables differed significantly when the two groups were compared. Lipase output, however, rose significantly in group S at 2 and $3 \mathrm{~h}$ postprandial. In group $\mathrm{O}$ lipase output increased in response to food intake, but the changes were not significant. Lipase production was significantly lower in group $\mathrm{O}$ than in group $\mathrm{S}$ throughout the experimental period (Fig. 2).

Finally, chymotrypsin activity and specific activity did not change significantly in 
response to food in either group. Olive oil, however, led to significantly higher values for both variables than sunflower seed oil. At $1 \mathrm{~h}$ after feeding, chymotrypsin production had risen in group $S$ to be significantly higher than in group $O$, whereas no change was seen in group $O$. No further significant differences between the groups were recorded during the remainder of the experimental period (Fig. 2).

\section{Duodenal $p H$}

Resting $\mathrm{pH}$ values of the duodenal contents were similar in both groups (6.4 (SE 0-25) with olive oil; 6.8 (SE 0.22) with sunflower seed oil). The presence of food led to a decline in $\mathrm{pH}$ which became significant from the second hour postprandially in both groups. Significant differences between the groups were not apparent until 4 and $5 \mathrm{~h}$ after food intake, when duodenal $\mathrm{pH}$ was lower in group $\mathrm{O}$ than in group $\mathrm{S}$ (Fig. 3).

\section{DISCUSSION \\ Resting conditions}

Under resting conditions and after the period of adaptation to the diet, mean pancreatic juice flow was similar to that recorded previously by Madrid et al. (1985) and Huertas et al. (1985) in dogs under identical experimental conditions, fed on a commercial dog chow ranging in fat content from 30 to $70 \mathrm{~g} / \mathrm{kg}$. This suggests that the volume of pancreatic juice secreted in the absence of stimuli is unaffected by the amount or degree of unsaturation of the dietary fatty acids. The production of bicarbonate under the present experimental conditions was significantly higher in comparison with the values obtained with low-fat diets in the two previously mentioned studies. No study to date has described the adaptation of bicarbonate secretion to different amounts of dietary fat, although high-fat diets as well as the intralumen administration of fatty acids have been shown to stimulate both the hydroelectrolytic and the organic component of the pancreatic juice secreted (Meyer \& Jones, 1974). Raising the amount of dietary fat also modifies plasma levels of secretin and cholecystokinin (CCK) (Modlin et al. 1979; Yamagishi \& Debas, 1980). We believe the rise in bicarbonate levels in pancreatic secretions may be related to changes in the level of these hormones in response to the increase in dietary fat.

The differences seen in the production of protein between groups $\mathrm{S}$ and $\mathrm{O}$ in the present study suggest that the degree of fatty acid unsaturation influences plasma protein levels. Several earlier studies have shown (Fink et al. 1983a; Hopman et al. 1985; Konturek et al. 1986) that oleic acid (the major fatty acid in the diet given to group $\mathrm{O}$ animals) is the most potent releaser of $\mathrm{CCK}$, itself a potent stimulant of the protein fraction of exocrine pancreatic secretion. However, oleic acid is also known to be a potent releaser of other gastrointestinal peptides able to inhibit exocrine pancreatic secretion, including peptide YY (PYY) (Pappas et al. 1985, 1986; Aponte et al. 1985) and PP (Fink et al. 1983 b). In dogs, the release of PYY by oleic acid has been shown to inhibit pancreatic secretion of proteins stimulated by submaximal doses of CCK (Pappas et al. 1985). This leads us to think that the reduced production of pancreatic proteins in the animals fed on olive oil may have resulted from the balance between the stimulating (CCK) and inhibiting (PYY and PP) effects of oleic acid (the major fatty acid in olive oil) on the protein fraction of pancreatic secretion.

The values for amylase activity and production published by Madrid et al. (1985) for dogs given a diet containing $50 \%$ less fat than in our study were markedly higher than our values for both groups. The differences may be due to the process of adaptation to highfat diets, as manifested in the rat pancreas by increases in lipase activity accompanied by 
a reciprocal decline in amylase activity (Deschodt-Lanckman et al. 1971; Snook, 1971; Saraux et al. 1982). The lower values in dogs given olive oil in the present study may reflect, as pointed out by Deschodt-Lanckman et al. (1971), the greater effectiveness of olive oil in inhibiting amylase, as compared with other sources of dietary fat such as tricaprylin and maize oil.

The activity and specific activity of lipase were apparently unaffected by the type of dietary fat provided and, thus, appear to change only in response to rising quantities of lipids (Bazin \& Lavan, 1979; Saraux et al. 1982; Sabb et al. 1986).

\section{Response to food}

Qualitative and quantitative differences between group $\mathrm{S}$ and group $\mathrm{O}$ were seen in pancreatic response to the two sources of dietary fat studied. Considering the values of duodenal $\mathrm{pH}$ and the composition of the diets, the secretory response to food would be expected to show patterns similar to those described by Madrid et al. (1985) and Huertas et al. (1985), who fed their animals with standard dog chow. The response may have been somewhat delayed, while the animals were fed with high-fat diets, as a result of delayed gastric emptying. The different responses to food in experimental groups $\mathrm{S}$ and $\mathrm{O}$ may be explainable in terms of the balance between those factors that stimulate and inhibit postprandial pancreatic secretion. The lack of response to food, as determined by the amount of bicarbonate and protein in pancreatic juice, may be traceable to the effect of oleic acid (in animals given olive oil) on the various factors involved in pancreatic response to food, as described previously for the resting condition. This monounsaturated fatty acid has been shown to be a potent stimulant of CCK (Hopman et al. 1985; Konturek et al. 1986) and secretin release (Kim et al. 1980; Fink et al. 1983 a), both of which are potent stimulants of pancreatic secretion. Oleic acid is also the most effective releaser of gastrointestinal peptides that inhibit both basal exocrine pancreatic secretion and secretion stimulated by submaximal doses of secretin and CCK, including PYY (Aponte et al. 1985; Pappas et al. 1986) and PP (Fink et al. 1983 b). Thus, the factors that favour and impede pancreatic secretion would reach equilibrium, leading in essence to a null change in pancreatic response (in terms of bicarbonate and protein levels) to the presence of food in the digestive tract.

The enzyme content in pancreatic juice secreted in response to food showed the same trends as were recorded under resting conditions. Amylase activity and production were lower in group $\mathrm{O}$, probably owing to the potent inhibitory effect of olive oil on amylase in comparison with other lipids such as tricaprylin and maize oil (Deschodt-Lanckman et al. 1971). Lipase production, but not activity, was affected by the degree of unsaturation of the dietary fat tested (Saraux et al. 1982). Chymotrypsin and amylase values showed opposite trends. Chymotrypsin activity and specific activity were higher in group $O$ animals throughout the postprandial period studied. The high oleic acid content of olive oil may explain the behaviour of these proteases, as this fatty acid is a potent releaser of CCK (Konturek et al. 1986), a hormone known to stimulate the organic component of pancreatic secretion (Mutt \& Jorpes, 1971; Modlin et al. 1979; Stubbs \& Stabile, 1985), especially proteolytic enzymes including chymotrypsin (Folsch et al. 1978).

Taken together, our findings show that exocrine pancreatic secretory activity in response to the presence of food is greater in dogs fed on a diet rich in sunflower seed oil (high polyunsaturated fatty acid content) than in animals given the same diet with virgin olive oil (rich in monounsaturated fatty acids) as the source of fat. In the latter group, postprandial secretory activity hardly changed in comparison with secretion under resting conditions. Parallel experiments have shown not only that there are no significant differences between group $\mathrm{O}$ and group $\mathrm{S}$ animals in digestive utilization of dietary fat and protein, but that in 
some cases the indices of nutritive utilization are actually higher in dogs adapted to a diet containing virgin olive oil (M. Mañas, F. J. Mataix, E. Martínez-Victoria and I. Seiquer, unpublished results). Such adaptation to dietary olive oil is a key advantage in terms of exocrine pancreatic economy, at least in this species.

The authors thank the Delegate for Provincial Promotion and Tourism of the Provincial Council of Jaén, Mr Isidoro Reverte, and the President of the Jaén Provincial Council, $\mathrm{Mr}$ Cristóbal López Carvajal, for their support and encouragement throughout the study. Virgin olive oil was kindly provided by the Patrimonio Comunal Olivarero. Our thanks also to Ms Karen Shashok for translating the original manuscript into English. This study was supported by the Provincial Council of Jaén (Spain).

\section{REFERENCES}

Aponte, G. W., Fink, A. S., Meyer, J. H., Takemoto, K. \& Taylor, I. L. (1985). Regional distribution and release of peptide YY (PYY) with fatty acids of different chain length. American Journal of Physiology 249, G745-G750.

Bazin, R. \& Lavan, M. (1979). Diet composition and insulin effects on amylase to lipase ratio in pancreas of diabetic rats. Digestion 19, 386-391.

Behrman, H. R. \& Kare, M. R. (1969). Adaptation of canine pancreatic enzymes to diet composition. Journal of Physiology 250, 667-676.

Bradford, M. A. (1976). A rapid and sensitive method for the determination of microgram quantities of protein utilizing the principle of protein dye-binding. Analytical Biochemistry 72, 248-254.

Bucko, A., Kopec, Z. \& Babala, J. (1969). Adaptation of amylase production in rat pancreas to altered glycide intake. Nutrition Dieta 11, 127-136.

Corring, T. \& Saucier, R. (1972). Secretion pancreatique sur porc fistulé. Adapation à la teneur en proteines du regime. (Pancreatic secretion in the fistulated pig. Adaptation to the protein in the diet.) Annales de Biologie Animale, Biochimie, Biophysique 12, 223-241.

Debas, H.R. \& Yamagishi, T. (1978). Evidence for pyloropancreatic reflex for pancreatic exocrine secretion. American Journal of Physiology 226, 39-44.

Deschodt-Lanckman, M., Robberecht, P., Camus, J. \& Christophe, J. (1971). Short-term adaptation of pancreatic hydrolases to nutritional and physiological stimuli in adult rats. Biochimie 53, 789-796.

Ekelund, K. \& Johanson, C. (1980). Output of bile and pancreatic enzymes after test meals with different fat content. Influence of body weight on pancreatic enzyme composition. Acta Physiologica Scandinavica 110, 161-165.

Emde, C., Liehr, R. M., Gregor, M., Pleul, O., Riecken, E. O. \& Menge, H. (1985). Lack of adaptative changes in human pancreatic amylase and lipase secretion in response to high-carbohydrate, low-fat diet applied by 10 day continuous intraduodenal infusions. Digestive Disease and Sciences 30, 204-210.

Faichney, A., Chey, W. Y., Kim, Y. C., Lee, K. Y., Kim, M. S. \& Chang, T. M. (1981). Effect of sodium oleate on plasma secretin concentration and pancreatic secretion in dogs. Gastroenterology 81, 458 462.

Fink, A. S., Luxemburg, M. \& Meyer, J. H. (1983a). Regionally perfused fatty acids augment acid-induced canine pancreatic secretion. American Journal of Physiology 245, G78-G84.

Fink, A. S., Taylor, I. L., Luxemburg, M. \& Meyer, J H. (1983b). Pancreatic polypeptide release by intraluminal fatty acids. Metabolism 32, 1063-1066.

Folsch, U. R., Wincker, K. \& Wormsley, K. G. (1978). Influence of repeated administration of cholecystokinin and secretin on the pancreas of the rat. Scandinavian Journal of Gastroenterology 13, 663-671.

Hickson, J. C. D. (1970). The secretion of pancreatic juice in response to stimulation of the vagus nerves in the pig. Journal of Physiology 206, 299-322.

Hoffman, G. (1963). Les Animaux de Laboratoire. Paris: Vigot Frères.

Hopman, W. P. N., Jansen, J. B. M. J. \& Lamers, C. B. H.W. (1985). Comparative study of the effects of equal amounts of fat, protein, and starch on plasma CCK in man. Scandinavian Journal of Gastroenterology 20, $843-847$

Huertas, J. R., Madrid, J. A., Salido, G. M., Mañas, M. \& Martinez-Victoria, E. (1985). Cimetidine modifies the late postprandial pancreatic hypersecretion in dogs. IRCS Medical Science 13, 635-636.

Kim, Y. C., Faichney, A. \& Ky, L. (1980). Endogenous release of secretin by sodium oleate in dog. Gastroenterology 78, 1195.

Konturek, S. J., Tasler, J., Bilski, J., Jong, A. J., Jansen, J. B. M. J. \& Lamers, C. B. (1986). Physiological role and localization of CCK release in dogs. American Journal of Physiology 250, G391-G397.

Low, A. G. (1982). The activity of pepsin, chymotrypsin and trypsin during $24 \mathrm{~h}$ periods in the small intestine of growing pigs. British Journal of Nutrition 48, 147-159. 
Madrid, J. A., Salido, G. M., Martínez-Victoria, E., Mañas, M. \& Mataix, F. J. (I985). Postprandial pancreatic exocrine secretion in dogs after oral administration of pirenzepine dihydrochloride. Drug Research 35. 15601562.

Malagelada, J. R, Dimango, E. P., Summerskill, W. H. J. \& Go, W. L. W. (1976). Regulation of pancreatic and gallbladder functions by intraluminal fatty acids and bile acids in man. Journal of Clinical Investigation $\mathbf{5 8}$ $493-499$.

Meyer, J. H. \& Jones, R. S. (1974). Canine pancreatic responses to intestinally perfused fat and products of fat digestion. American Journal of Physiology 266, 1178-1187.

Modlin, I. M., Hansky, J., Singer, M. \& Walsh, J. H. (1979). Evidence that the cholinergic enteropancreatic reflex may be independent of CCK release. Surgery USA 86, 352-361.

Mutt, V. \& Jorpes, E. (1971). Hormonal peptides of the upper intestine. Biochemical Journal 125, 57P-58P.

Negrel, R., Serrero, G., Fernández López, V. \& Ailhand, G. (1976). Esterolytic activities of rat intestinal mucosa. European Journal of Biochemistry 71, 249-258.

Noeiting, G. \& Bernfield, P. (1948). Sur les enzimes amilolytiques. III. La $\alpha$-amylase dossage d'activité et contrôle de l'absence de $\beta$-amylase. (On amylolytic enzymes. III. Analysis of $\alpha$-amylase activity and testing for the absence of $\beta$-amylase.) Helvetica Chimica Acta 31, 286-290.

Pappas, T. N., Debas, H. T., Chang, A. M. \& Taylor, I, L. (1986). Peptide YY release by fatty acids is sufficient to inhibit gastric emptying in dogs. Gastroenterology 91, 1386-1389.

Pappas, T. N., Debas, H. T., Goto, Y. \& Taylor, I. L. (1985). PYY inhibits meal stimulated pancreatic and gastric secretion. American Journal of Physiology 248, Gl18-G123.

Partridge, I. G, Low, A. G., Sambrook, I. E. \& Corring, T. (1982). The influence of diet on the exocrine pancreatic secretion of growing pigs. British Journal of Nutrition 48, 137-146.

Rebound, J. P., Ben Abdeljlil, A. \& Desnuelle, P. (1962). Variations de la teneur en enzymes du pancreas de rat en fonction de la composition des regimes. (Variation of the amount of pancreatic enzymes of the rat in relation to diet composition.) Biochimica et Biophysica Acta 58, 326-337.

Robberecht, P., Deschodt-Lanckman, M., Camus, J., Bruylands, J. \& Christophe, J. (1971). Rat pancreatic hydrolases from birth to weaning and dietary adaptation after weaning. American Journal of Physiology $\mathbf{2 2 1}$. $376-381$

Sabb, J. E., Godfrey, P. M. \& Brannon, P. M. (1986). Adaptative response of rat pancreatic lipase to dietary fat. Effects of amount and type of fat. Journal of Nutrition 116, 892-899.

Saraux, B., Girard-Globa, A., Ouaged, M. \& Vacher, D. (1982). Response of the exocrine pancreas to quantitative and qualitative variations in dietary lipids. American Journal of Physiology 243, G10-G15.

Simoes-Nunes, C. (1985). Effects de la teneur et de la nature des lipides du régime alimentaire sur l'adaptation de la lipase pancréatique chez le pore. (Effects of the amount and kind of dietary fat on the adaptation of pancreatic lipase in the pig.) Reproduction, Nutrition, Développement 25, 809.

Snook, J. T. (1971). Dietary regulation of pancreatic enzymes in the rat with emphasis on carbohydrates. American Journal of Physiology 221, 1383-1387.

Stubbs, R. S. \& Stabile, B. E. (1985). Role of CCK in pancreatic exocrine response to intraluminal amino acids and fat. American Journal of Physiology 248, G347-G352.

White, T. T. \& Murat, J. E. (1967). Les pancréatitis. Étude Clinique Experimentale et Thérapeutique. (Pancreatitis: Clinical, Experimental and Therapeutic Study), pp. 39-92. Paris: La Expansion.

Wicker, C. \& Puigsever, A. (1987). Effects of inverse changes in dietary lipid and carbohydrate on the synthesis of some pancreatic secretory proteins. European Journal of Biochemistry 162, 25-30.

Yamagishi, T. \& Debas, H. T. (1980). GIP is not the mediator of the enterogastrone action of fat in the dog. Gastroenterology $78,931-936$. 